\title{
Inquietações da adolescência: da redoma da Casa Grande ao mergulho no tempo presente da cidade
}

\section{Concerns of adolescence: from the dome of Casa Grande to the plunge into the present time of the city}

Ismail Xavier ${ }^{1}$ 


\section{Resumo}

O artigo analisa Casa grande, dirigido por Fellipe Barbosa, em 2014, centrado no estudo do motivo temático "o passado no presente" na composição da trama. Motivo temático é cada uma das unidades do campo temático de uma narrativa detectada pela sua análise (Tomachevski, 1970). A trama do filme se concentra no percurso de um adolescente superprotegido por sua família rica, que guarda sobrevivências de um modus vivendi intramuros próprio do poder senhorial do passado. Uma forte crise nas finanças do Pater familias o obriga a reduzir o cordão de proteção ao filho, que passa a ir ao colégio de ônibus, iniciando uma nova vivência na cidade do Rio de Janeiro. Ou seja, ele realiza seu efetivo mergulho no tempo presente, experiência que o amadurece em várias frentes.

Palavras-chave

Sobrevida do passado no presente, crise da família patriarcal, ansiedades sexuais da adolescência, motivo temático, estratos do tempo.

\section{Abstract}

This article is an in-depth analysis of Casa Grande, a film by Felipe Barbosa (2014). It is a study focused on the thematic motive "the past in the present" as a central component in the development of the film's plot. The notion "thematic motive" refers to each unit of the thematic range of a narrative as identified by its analysis (Tomachevski, 1970). The film plot is concentrated in the story of a teenager over-protected by his rich family that keeps alive a code of behavior proper to the patriarchal paradigms of powerful Brazilian rural families in the past. An acute and unexpected crisis comes to his father economic affairs obliging him to cut expenses and dismiss the professional driver that used to take his sun to school. Jean, the teenager, starts going to high school by bus and starts to face the big city as it is lived by those who interact with distinct social classes and has to face new challenges. The new experiences give him opportunities to learn how to find his way in a contemporary society. By dealing with those challenges, he plunges into a process of ripening, in particular on what concerns his sexual anxiety.

\section{Keywords}

The survival of the past in the present, the crisis of patriarchal family, teenager's sexual anxiety, the notion of thematic motive, time stratums. 
Observando filmes brasileiros das primeiras décadas deste século, percebese que há uma reiterada presença de um tipo de interação marcado pelo motivo temático "o passado no presente". Esse motivo significa algo distinto de uma injunção da memória pessoal no dia a dia, algo subjetivo que, uma vez lembrado, tem efeito no presente. Trata-se de um fato que se pode verificar a partir da figura de um retorno, seja de uma personagem ou de um vestígio material do passado que vem à tona, gerando novas tensões num ambiente e vindo ao centro da trama.

Essa noção de "motivo temático" é usada aqui na acepção de Tomachevski, em sua teoria do discurso narrativo. Ela envolve a lida com categorias da análise formal que dizem respeito ao "momento da elaboração" da temática escolhida. Ou seja, momento em que o campo temático da obra é decomposto em unidades que se articulam na trama, unidades que ele denomina "motivos" cujo conjunto compõe a narrativa (Tomachevski, 1970).

Tenho usado essa noção em estudos comparativos de filmes que trazem o motivo temático "o passado no presente" inserido de forma articulada a outros motivos. Definido o terreno em que vamos caminhar na análise do filme Casa grande, dirigido por Fellipe Barbosa, em 2014, vale uma rápida contextualização para situar o traço específico que permite determiná-lo como uma variante original, considerado um conjunto de obras nas quais esse motivo temático tem papel central na composição.

\section{Dados de contexto e instrumentos de análise do filme}

Quando eu era vivo, de Marco Dutra (2014), traz a presença deste motivo temático na forma do retorno de um filho, recém-separado de sua esposa, à casa do pai, um prédio de apartamentos localizado num bairro de classe média de São Paulo. O reencontro se dá depois de longa ausência e não é nada tranquilo. Tensões de várias ordens se criam pela maneira como há diferenças na lida com os objetos ligados à memória da mãe morta. Seus pertencentes e documentos estão jogados nos cantos e o filho quer organizá-los. Por outro lado, a convivência é temperada pela presença de uma moça a quem o pai alugou o quarto que no passado era do 
filho. A trama se desenvolve em torno dessas personagens e terá como referência quase exclusiva o apartamento, onde se dá o ajuste de contas entre pai e filho.

No filme Obra, de Gregório Graziosi (2014), temos um segundo tipo de retorno ao passado. Está aí em foco a verticalização de São Paulo e os métodos da indústria de construção civil, responsável pela "selva de concreto" já em estado terminal de adensamento, quando estão consagradas as implosões ou simples demolições como forma de "criar espaços". Essa indústria é o campo de operações do protagonista, um arquiteto erudito que, na primeira cena do filme, discorre sobre os problemas subjacentes a esses métodos de expansão das torres que são emblemas da arquitetura moderna. Na visita a um terreno de sua família onde ele vai conduzir uma obra, examina o solo onde será instalada a estrutura que vai sustentar a edificação. Ao revirar a terra, encontra cadáveres inesperados, uma experiência geradora de uma forte crise pessoal. Ele é levado a repensar a forma como seu ofício se insere numa tradição familiar intimamente ligada ao processo de rápida transformação do centro da cidade de São Paulo.

No momento em que os corpos foram ali enterrados, seu avô já era o proprietário do terreno, estando sua família comprometida com esta anomalia indicadora de um gesto ilegal, sem excluir a hipótese de serem ossadas de desaparecidos políticos do período da ditadura. A partir desse fato, João Carlos, o arquiteto, revive velhas tensões em seu contato com a figura paterna e seus familiares. Em seu mal-estar, uma pergunta persiste: quem eram estas pessoas?

Quem convive de perto com a crise do protagonista é sua esposa que, por ironia, é uma arqueóloga cuja vida é feita da remoção de camadas dos mais antigos subterrâneos da cidade para tornar um passado remoto visível, trabalho que torna seus achados documentos histórico-geológicos de interesse científico. Um ofício que está nas antípodas das providências dos construtores em sua relação com o solo. Neste momento difícil, o abalo põe em risco o convívio do casal. Algo que os dois devem equacionar em conjunto.

Além da presença do motivo temático comum a Casa grande, há em Obra um apuro formal nos enquadres em planos fixos que aproxima os dois filmes, 
embora lidem com espaços urbanos bem distintos. Assim como há um significativo dado formal que reforça as semelhanças, malgrado a diferença de ambiente e de questões específicas que afetam as personagens; o uso da tela ampla na horizontal, tipo cinemascope, que sublinha aspectos do habitat das personagens ligados a um senso de ordem geométrica que, em cada filme, ganha distintas conotações.

Para a caracterização do contexto em que se insere Casa grande, foram citados dois filmes de São Paulo entre um conjunto que tem no motivo temático "o passado no presente" um eixo fundamental. Para completar, inclusive o quadro conceitual que orienta este artigo, vale mencionar dois filmes pernambucanos, estado que reúne o maior elenco de obras em meus estudos com este recorte. Alguns trabalham a presença deste motivo temático associado à migração do protagonista do litoral para o interior, quando tal deslocamento geográfico traz um movimento no tempo. Ele adentra regiões nas quais a estrutura de relações de trabalho, o caráter da propriedade e as efetivas leis da família patriarcal, em sua postura senhorial e arbítrio de mando, continuam vigentes. O passado sobrevive no presente e incide com vigor na vida de personagens vindas da cidade grande.

Um exemplo é Árido movie, de Lírio Ferreira (2005), que trabalha o motivo "do passado no presente" numa trama que envolve como protagonista um jovem que vive em São Paulo, sendo repórter-âncora do telejornal de uma rede nacional. Pessoa, enfim, bem conhecida. Ele recebe a notícia da morte do pai na sua pequena cidade natal no interior de Pernambuco. Em regime de urgência, faz a viagem para poder acompanhar o enterro, estando a família à espera para poder realizá-lo com sua indispensável presença. Chegando lá, fica sabendo da causa mortis de seu pai: foi assassinado. Fato que, segundo manda a lei da tradição local, torna seu dever participar da ação de vingança que cabe aos descendentes: matar o culpado. A partir dessa situação, desenvolve-se a trama mobilizando muitas personagens da região, que encontram no filme um painel de suas experiências no plano social e religioso. Assim que suas questões se resolvem, nem tudo nos termos da exigência familiar, o repórter volta a São Paulo trazendo consigo registros de sua vivência nesse contato. 
Em Árido movie, já se faz presente um traço da ordem social brasileira: suas desigualdades estruturais entre regiões, que terão lugar em outros filmes na conjuntura dos anos 2000. O protagonista chega ao Recife e encontra velhos amigos que o levam de carro até o sertão. Há nesse movimento um recuo no tempo em direção a um Brasil onde persiste a ordem patriarcal senhorial. Esse tipo de sobrevida será aqui trabalhado a partir da noção de "estratos de tempo", elaborada pelo historiógrafo Reinhart Koselleck (2014).

Ele observa que o decurso do tempo envolve camadas simultâneas que não se movimentam de modo idêntico, comportando distintos ritmos e velocidades de manifestação num processo que depende do espaço e de escalas de observação. Uma ocorrência pode se dar como fato contingente quando observada dentro do escopo da vida de um indivíduo ou de uma família, sendo vivida (e depois relatada) como algo singular, inesperado. Como este caso do pai do repórter. No entanto, quando vista em outra escala e envolvendo uma ordem mais ampla de fatos que dizem respeito a grupos maiores de indivíduos e, no limite, a toda uma ordem social, ela se mostra um tipo de ocorrência que se dá como fato regular, previsível dentro dessa ordem, até mesmo característico dela.

O filme de Kleber Mendonça $O$ som ao redor (2012) é um paradigma nessa composição de uma trama que evidencia a convivência de estratos de tempo distintos no contexto contemporâneo. Seu desenvolvimento tem esta condição como um dado estrutural. Movidos por uma incisiva manifestação de jogos de poder e ações próprias a uma ordem social do passado, cidadãos da cidade grande vivem conflitos nos quais o tradicional e o moderno convivem no mesmo espaço social. A trama se desenvolve acoplada a essa superposição de estratos do tempo, pensados em termos da ordem econômico-social.

Um senhor de engenho vive agora no Recife, com sua família espalhada em diferentes apartamentos e casas de um bairro litorâneo da cidade. O lugar de origem de sua fortuna é agora uma fazenda à qual ele retorna em alguns 
momentos, nos quais ela vale mais como local de lazer do que como fonte de renda, embora ainda mantenha alguma estrutura e empregados ligados ao passado. Seu Francisco está hoje mais concentrado nos negócios imobiliários, dado que, com sua fortuna, acumulou propriedades no bairro onde mora. Seus descendentes mantêm em seus apartamentos o mesmo tom de relação com suas empregadas domésticas que vivem como agregadas em suas propriedades, o que veremos também em Casa grande, filme que se passa no Rio de Janeiro.

A montagem da trama de $O$ som ao redor caracteriza muito bem a situação da família no Recife - uma parte vivendo de rendas e uma do negócio imobiliário gerado pela fortuna do avô. Tudo à volta é monitorado por eles, inclusive a segurança do bairro, uma vez que há ao lado uma favela vista como ameaçadora. No momento, o bairro moderno marcado por aquela verticalização sem controle, própria das nossas grandes cidades, é a efetiva esfera de influência de Seu Francisco e família. Um lugar onde ele imprime um modus operandi nas relações sociais, regulado, dentro do possível, nos termos da ordem do engenho. Há o momento em que um grupo de jovens chega ao bairro e oferece o serviço de guardas noturnos a Seu Francisco, ganhando a sua benção, que é corroborada pelo apoio da família e outros vizinhos. É em torno desse grupo que a trama passa a se organizar, trabalhando sua relação, às vezes tensa, com a família do senhor de engenho. Mais para o final da narrativa, este entra em contato com o líder do grupo e marca uma conversa. O líder e seu irmão vão ao apartamento de Seu Francisco, que esclarece precisar da ação deles como seus guarda-costas, pois mataram um de seus homens de confiança na zona do engenho e ele tem de estar preparado para alguma ação contra ele. Os dois, para sua total surpresa, revelam ter sido eles que mataram tal homem de confiança e que são filhos de uma pessoa que o senhor de engenho mandou matar quando eles eram crianças. Neste momento, consumam sua promessa de vingança e, marcando a vigência da lei da tradição, matam o Seu Francisco. Está selada a presença, no Recife, da 
regra do mundo do engenho a se afirmar em pleno bairro moderno. Um exemplo dramático de superposição de estratos de tempo.

Segundo Koselleck, quem analisa uma comunicação narrativa não raro enfrenta a presença de ocorrências atinentes a estratos distintos do tempo que interagem na trama, de modo a articular camadas simultâneas e superpostas de tempo que se relacionam de modo peculiar. O filme Casa grande, objeto central deste artigo, será aqui analisado a partir do mesmo referencial que o filme de Kleber Mendonça. A diferença fundamental entre ambos face a Árido movie é o fato de que, neles, os estratos distintos convivem na mesma cidade, valendose do contexto urbano-geográfico como lugar de interação onde os movimentos dos protagonistas, suas motivações, conflitos e a realização de seus anelos se dão no seio de tal superposição, que têm papel decisivo na trama.

\section{O filme Casa Grande e seu modus operandi visual}

No caso do filme de Fellipe Barbosa, a figura senhorial é bem distinta do Seu Francisco. Aqui, o pai de família é mais jovem, em todos os sentidos, mais moderno e totalmente inserido no mundo contemporâneo do capital financeiro. É um economista e ex-banqueiro que ampliou sua fortuna em especulações no mercado, um homem que há algum tempo vive de rendas e sustenta a sua família no fausto. O casal, seu filho e sua filha moram numa mansão na Barra da Tijuca construída por ele com muito orgulho, fazendo parte de um desses condomínios fechados de gente rica nas grandes cidades, um enclave que se fecha e se arma de dispositivos de segurança, se apartando dos contatos próprios à vida urbana, compondo um modo de vida peculiar em nome da segurança e dos velhos costumes, conforme analisado por suas implicações psicossociais no excelente livro de Cristian Dunker (2015).

$\mathrm{Na}$ abertura do filme, os créditos desfilam tendo como pano de fundo uma longuíssima tomada da mansão, num plano geral que a exibe em toda a sua completude numa imagem marcada por expressiva simetria, ressaltada pelo formato escolhido para a projeção do filme, tipo cinemascope. 


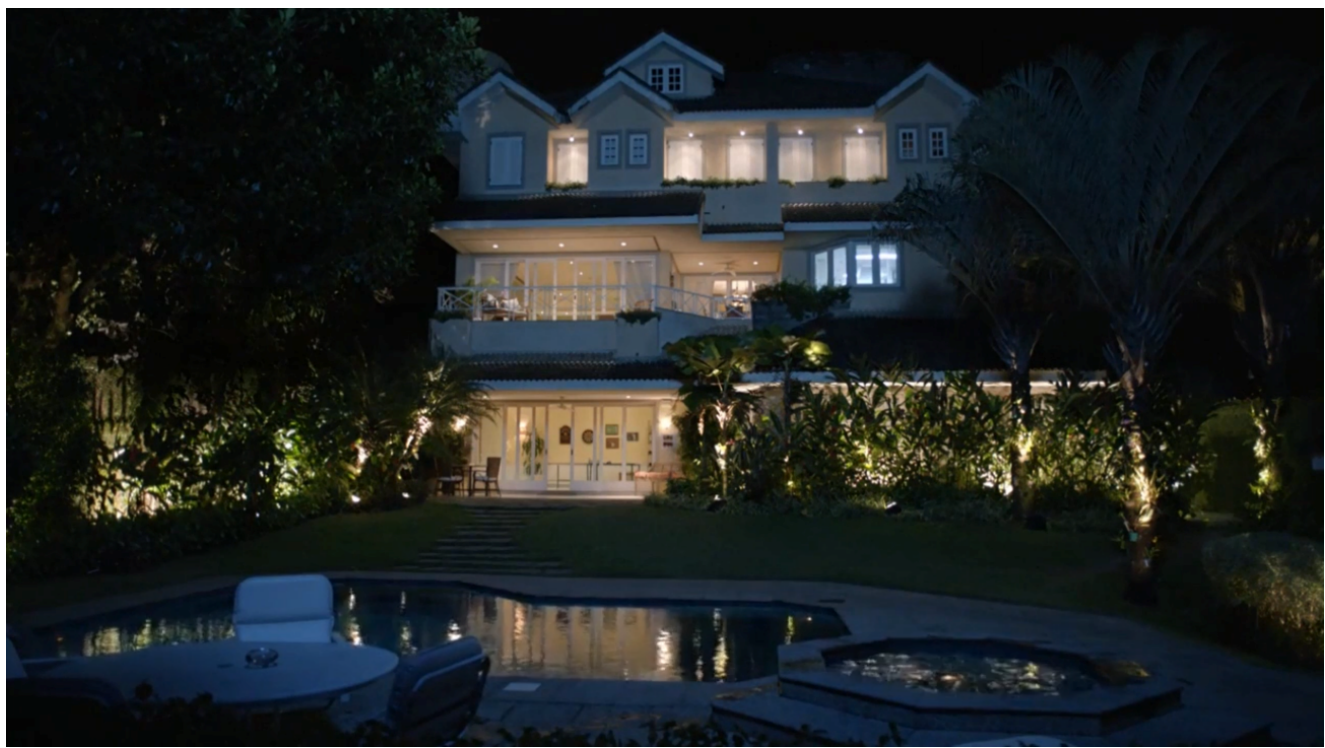

Figura 1

Vista num plano geral que exibe a área de lazer na parte traseira da casa, na simetria perfeita de um enquadre frontal, a Casa Grande exibe um jardim e a enorme piscina onde o dono da casa se movimenta e, em seguida, se recolhe na mansão de três andares. Mais tarde, veremos que acima estão os dois andares de uso privado da família do proprietário. Junto ao solo, a ala de serviços, a cozinha e as várias salas de estar e recepção de convivas. A área das empregadas é separada e tem uma entrada lateral. O terreno e a forma como é ocupado viabilizam uma nítida distância frente ao mundo exterior. Tudo se ajusta muito bem ao desejo de seu proprietário que, visto a distância, entra na casa enquanto as luzes vão se apagando. Ao longo do filme, vemos o jardim da frente e a fachada da casa, observados da calçada, tudo exibindo a mesma ordem e simetria.

Nesse espaço se desenvolvem as relações entre as personagens, sejam as que envolvem patrões e empregados, seja a que define o esforço dos pais em blindar os movimentos do filho e da filha pela cidade do Rio de Janeiro.

Ao longo do filme, há uma economia de planos na composição das cenas, que ganham uma decupagem bem ajustada para dar conta da interação entre as personagens e fazer fluir a narrativa. Prevalece a atenção à ordem do espaço associada à arquitetura e à composição dos ambientes. Há um fluxo linear no andamento da 
trama, um estilo visual e sonoro que dá fluência à sucessão das cenas, dentro de uma sobriedade de estilo que é mais pronunciada quando está em foco a ordem da Casa Grande. Um estilo mais descontraído emerge à medida que o percurso de Jean, o adolescente protagonista, avança extramuros por uma nova situação em que mergulha de vez no estrato de tempo mais dinâmico da vida contemporânea.

\section{A Casa Grande e seu modus operandi intramuros}

Não falta espaço nem trabalho para os que lá estão para preparar refeições, cuidar da conservação e da limpeza da casa, do jardim e da piscina. Temos de imediato o emblema referido no título: um privilégio de classe e uma forma de convivência que dá continuidade à tradição patriarcal, que, neste caso, será trabalhada como expressão de um senso de proteção e afastamento em face da cidade do Rio de Janeiro moderno, com sua agitação, espaços superlotados, problemas de transporte e desigualdade social pronunciada, características que as favelas de todo Brasil simbolizam. A favela da Rocinha, que fica no caminho de quem sai da Barra e se dirige para outros bairros da cidade e ao centro, se expandiu numa área junto à qual os ricos transitam com seus carros em elevados, que transformam tudo o mais em vistas da cidade, um ponto da paisagem urbana a ser observado em movimento.

O filme põe em foco uma elite carioca que se deslocou para a Barra da Tijuca para viver num ponto não atingido pelo rápido adensamento da malha urbana e pela sociabilidade do esquema apartamento-calçadas repletas. Um estilo de vida e uma experiência de propriedade expressos neste isolamento com seus rituais de segurança que envolvem a todos, em especial os criados em suas obrigações. A ideia é observar tal estilo de relação de classe e a convivência entre patrões e empregados que, como já se observou, resulta de uma longa sobrevida da tradição senhorial das propriedades rurais dos séculos passados. O título do filme evoca o célebre binômio Casa Grande e Senzala, de modo a sugerir esta herança de estilo e forma de poder que permite associar aquela tradição à sua versão moderna, claro que com o devido ajuste ao novo patamar tecnológico e a um novo quadro social de trabalho assalariado. 
Como já apontado, é sensível a afinidade de Casa grande com O som ao redor no tratamento da atmosfera e na feição das relações patrão-empregado. Pode-se dizer que o filme de Fellipe Barbosa é até mais incisivo em seus protocolos senhoriais, visto o senso mais nítido de isolamento criado no enorme espaço da morada como um emblema de classe.

A primeira cena no seu interior traz o adolescente Jean a pentear os cabelos, preparando-se para descer os lances de escada e se dirigir para a ala, que fica fora do corpo central da Casa, onde está Rita, uma das empregadas. Bate à porta e ela o faz entrar. Segue-se o plano dos dois sentados num sofá, recostados na parede e vistos em imagem frontal num único plano que dá conta do episódio. A atitude dela ao recebê-lo deixa claro que não se trata de uma primeira vez. Eles permanecem bem aconchegados, corpo a corpo. Vez ou outra, a mão dele faz carinho na perna dela. Isso enquanto ela, muito animada, Ihe conta em detalhes uma transa muito especial com "o cara" num dia de folga. Em matéria de sexo, ele comenta sua inexperiência. Faz um movimento de aproximação tentando beijá-la, o que ela rejeita dizendo: "tá louco?". A tentativa de Jean de ir adiante como uma espécie de aula prática a receber de Rita não se consuma. Tudo se passa com afeto e empatia, mesmo a forma da recusa. O plano único traz fluência a esta conversa corpo a corpo. E chega a hora em que ele tem de voltar para o seu quarto sem ser visto pela família.

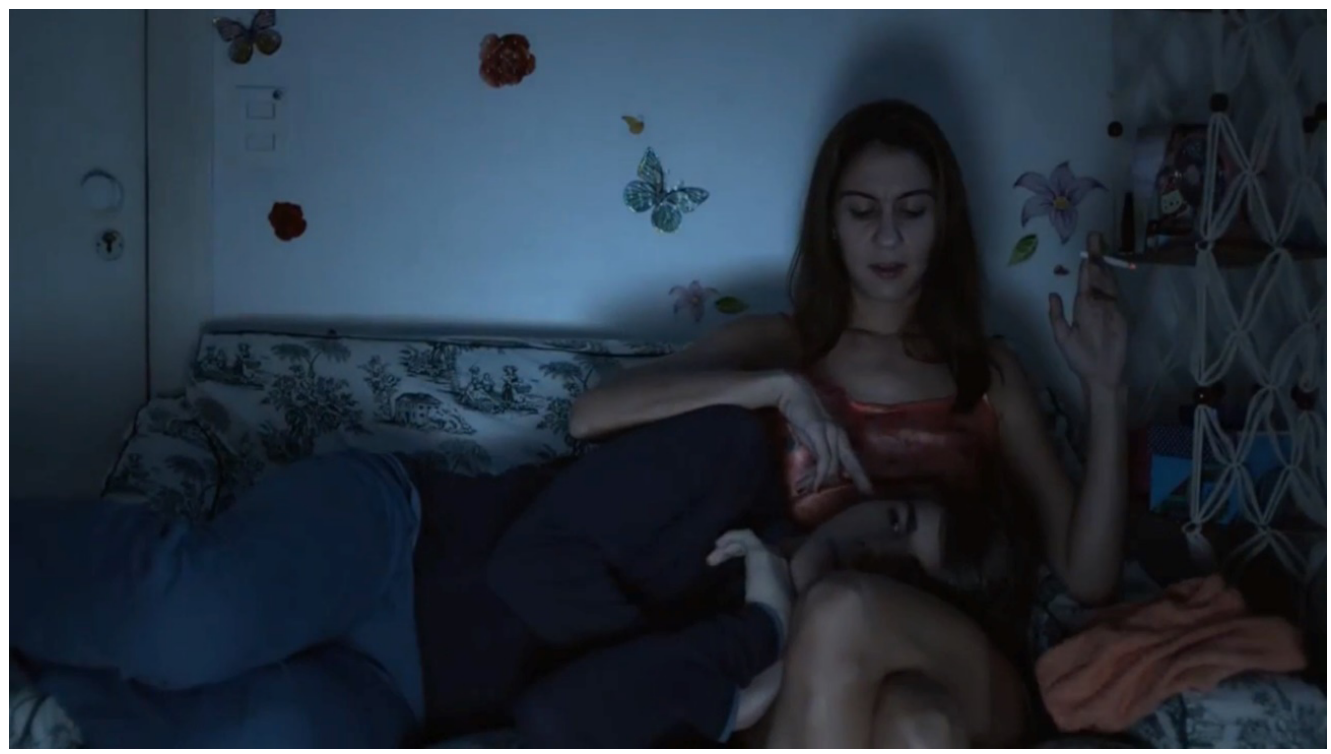

Figura 2 
Essa sequência do encontro noturno lembra um lance que vem da tradição senhorial, em que a iniciação sexual do filho não raro era feita em casa numa relação com serviçais. Este prevalecer de costumes próprios a tal tradição das grandes fazendas - ou nos termos aqui em pauta, a vigência de um estrato de tempo passado cuja superação foi lenta demais e, em muitos casos, não se completou - não se dá em sua plenitude. Para tanto, precisaria daquela redoma isolada sob o poder absoluto do patriarca. Condição ausente num momento em que a amplitude de movimentos de quem, estando no serviço doméstico, tem fora dele experiências geradoras de outros comportamentos que não a subserviência integral aos donos da casa. Permanece de forma variada a informalidade, à moda do passado, na relação patrão-empregados: sem contrato, sem pagamento dos direitos trabalhistas previstos em leis, que só foram estendidas a empregada(0)s doméstica(o)s pouco tempo antes do momento em que se passa a trama.

Nesse sentido, não se pode dizer de forma absoluta que não há nada de novo na Casa Grande. Temos um quadro de relações que traz um detalhe importante: Rita, a empregada que veio do Nordeste, ao receber as visitas de Jean, age como amiga e conselheira, mulher que permite certas intimidades no corpo a corpo no sofá-cama, mas que reserva o direito de não se tornar um objeto sexual por força de sua condição de serviçal da casa. Seu mundo abriga outras referências que Ihe fazem mais esperta, sem entregar de todo a sua liberdade nas mãos de seus patrões, uma alternativa que antigos serviçais, mesmo muito depois da abolição da escravatura, não teriam.

Estando em pauta o esforço de sobrevida próprio a um estilo de vida que, na medida do possível, mantém tradições da velha ordem, é importante observar que a nota dissonante geradora de uma quebra dessa tradição vem de Jean, por força de uma inquietação cultural e dedicação à música. São frequentes as situações em que, junto a amigos ou sozinho, o vemos tocar violão. Estudar música é uma opção de carreira a se considerar, tendo em vista o vestibular que se avizinha. Opção que não é citada numa conversa com o pai sobre carreiras profissionais a abraçar. Ele fala que sua primeira opção é o curso superior de comunicação, 
citando direito como segunda opção. O pai Ihe diz: "Comunicação é piada". Como sua lista não inclui o estudo de economia, para desgosto do pai, este aproveita e elogia um colega do filho por tal escolha e diz: "o seu colega vai ficar rico".

No fundo, fala de si próprio, pois em outra cena o vemos no seu escritório sentado diante do computador on-line, falando de sua "carreira no banco" que ele saiu para cuidar da vida de investidor. Já nesta cena, vem o tema das vagas na universidade pública, quando ele expressa seu ceticismo face à questão das cotas para jovens negros, só não atacando a nova medida porque a implantação de cotas segue o exemplo dos Estados Unidos - seu modelo ideal de sociedade.

A irmã mais nova de Jean, Natalie, a outra representante da geração no seio da família, recebe, ao longo do filme, muito menos atenção. Sua presença, fala e ação tendem a estar relacionadas com as cenas em família à mesa e uma ou outra conversa com a mãe ou com o irmão. Em verdade, a exígua atenção dada a ela, principalmente no caso do pai, é marca de uma hierarquia no tocante à questão de gênero que se expressa neste dia a dia, mesmo que se leve em conta o fato de Jean ser o protagonista da narrativa. O irmão recebe maior atenção de todos e, em especial da câmera, quando presente em cena, sobretudo nos momentos em que está com o violão enquanto a conversa rola à sua volta, até mesmo em meio a uma reunião de estudos com os amigos em casa. As conversas entre pai e mãe têm sempre conexão com questões da vida prática. E a relação deles com Rita e Noêmia, a outra empregada, exceto em um momento de confronto que terá maior consequência, é sempre definida em cenas curtas.

Uma cena em que Natalie ganha protagonismo se dá no closet dos pais, marcada por uma ação desabonadora. Há um armário de roupas onde havíamos visto o pai esconder um bom maço de dinheiro; e lá está ela a surrupiar algumas notas (será a culpa depois jogada nas empregadas?). O irmão aparece e a surpreende. Exige que devolva o dinheiro, mas ela insiste em levar até o fim sua empreitada. Ele avisa que vai contar para o pai sobre o episódio. Em resposta, ela diz que irá denunciar suas idas noturnas ao quarto de Rita. Sabe que os novos tempos tornam oportuna a manutenção de tais intimidades em segredo, às vezes a partir de um 
jogo de subentendidos, mesmo que o silêncio se dê muito mais por conveniência, por uma questão da imagem da família ou por receio de um eventual processo movido pela empregada. Neste caso, esse saber da irmã, uma vez trazido aos pais, teria forte efeito.

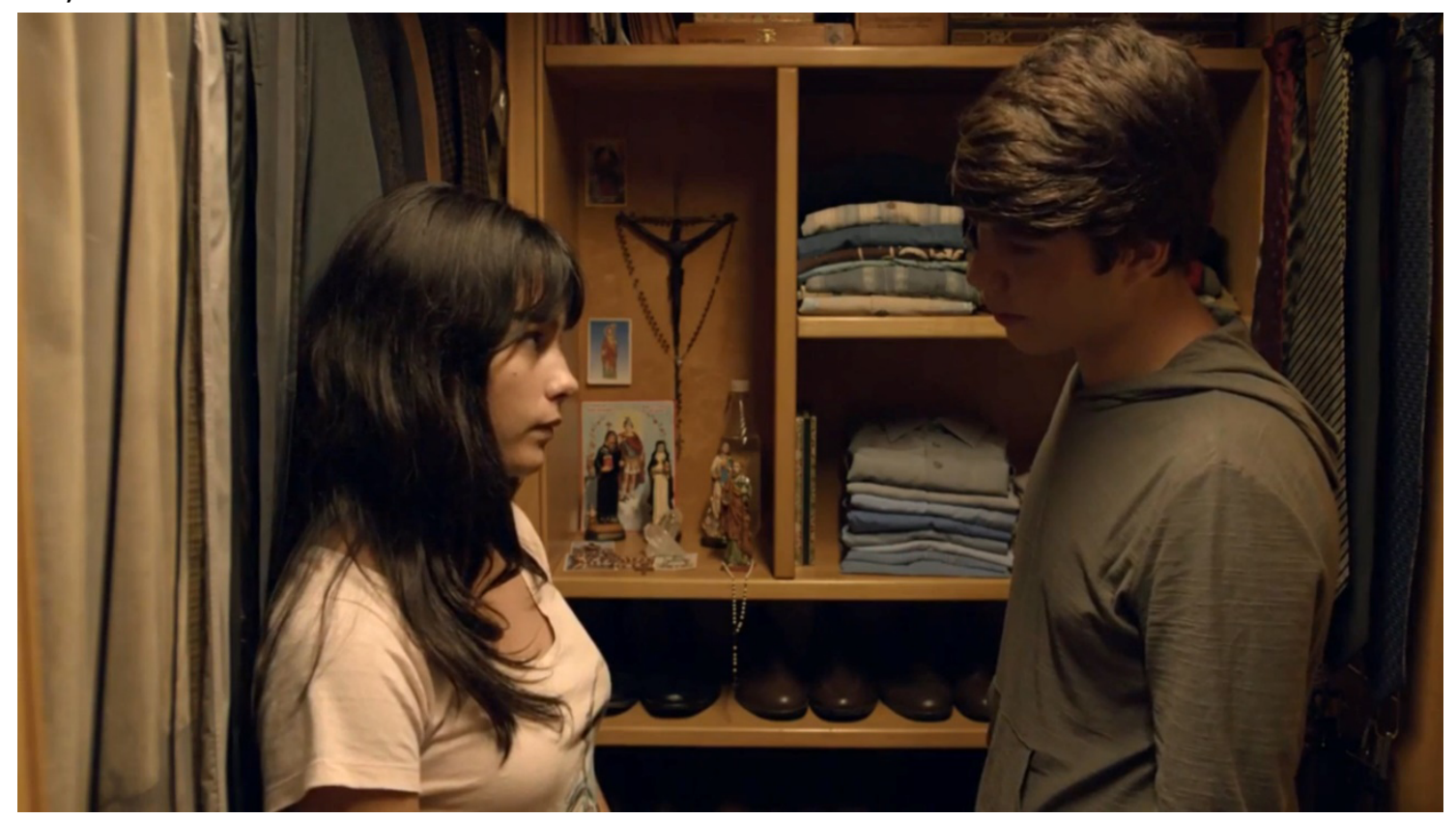

Figura 3

Mais adiante, numa tarde em que Jean está só no seu quarto com uma namorada, o pai vai intimá-lo e a destrancar a porta dizendo: "Jean, você tem uma irmã". O que evidencia as razões de tal interdição.

Quanto a Jean, dentre as providências que a família toma para protegêlo está o imperativo de manter um cordão de proteção quando está fora de casa. Ele vai para o Colégio São Bento, localizado no centro da cidade, ponto de contato dos adolescentes (só do sexo masculino), moços bem-nascidos que lá encontram um ensino de qualidade e ajustado às expectativas de seus pais. Acompanhamos Jean em uma ou outra aula, setor onde faz suas malandragens, colando numa prova e dando pouca atenção a alguns professores. A primeira vez que o vimos em classe, ele estava dormindo para compensar a noite com Rita, visto a prioridade dada a sua desinibição sexual que não deslancha. Ele está ansioso, pois considera que já está passando da idade. Há conversas com os 
colegas e a turma de amigos sobre o assunto, dentro de um clima de desafios, provocações e piadas, tudo na base do bom humor, papos aos quais ele adere, mas se mantendo discreto.

O cordão de proteção administrado pelo pai tem um elo forte com Severino, o motorista da Casa Grande, que todo dia leva Jean para o colégio e vai buscá-lo. Dentro do possível, também o atende nas idas e vindas dos programas noturnos com os amigos. Isso gerou uma amizade entre eles que fez do motorista um parceiro de muita conversa, alguém em que ele pode confiar. Um clima propício a pedidos de conselhos fora de questão na relação com os pais: "o que faço para passar do beijo?". Severino responde que a levaria ao forró para dançar, abraçar, beijar, criando um clima para ir adiante: "tem de ser pegador, mulher gosta de homem".

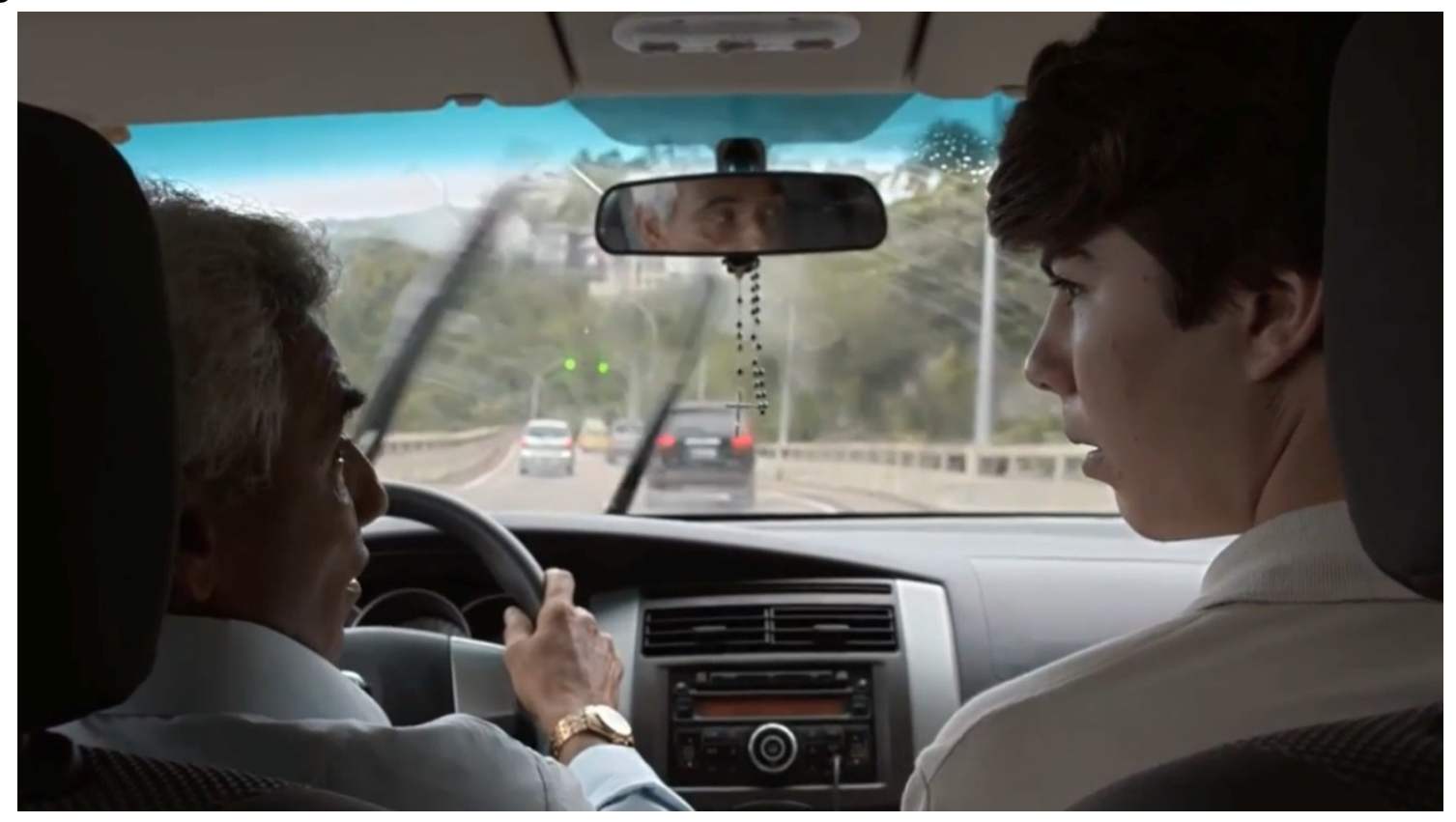

Figura 4

Jean é acompanhado em todos os seus movimentos fora de casa, até que a crise nas finanças leva o pai a ir além nas conversas com Sônia, sua mulher, sobre a necessidade de conter despesas. Providência em que ela colabora, anunciando que pode passar a trabalhar em vendas de artigos de uso pessoal para amigas. Pois, como ela diz: "ninguém toca na poupança dos meninos". 
A crise financeira se agrava e, quando se vê diante de uma grave debacle, Hugo Cavalcanti é obrigado a cortar despesas de forma mais radical, o que inclui despedir Severino de sua função. Tal crise foi anunciada por breves cenas em que vimos o pai lidando com seus negócios por telefone, geralmente com corretores para tomar decisões. Há lances de dívidas não pagas e uma ocasião, por exemplo, em que no colégio, um colega acusa o pai de Jean de ter roubado o pai dele, gerando uma ameaça de briga, evitada pelos colegas.

\section{O salto de Jean para o contemporâneo extramuros}

O pai avisa seu filho de que Severino vai "sair de férias", ver seus parentes na Paraíba. Para ajeitar a questão do dia a dia de Jean e para que tudo no colégio continue como antes, ele passará a ir para lá todos os dias de ônibus. Sobram ainda regras para a versão noturna dos movimentos do filho, havendo a partir daí proibições e exigência de cumprimento de horários de volta. Na primeira ocasião de um programa com os amigos num bar, animado, o pai exige um limite de horário e insiste em ir buscá-lo. Ao estacionar em frente ao bar, surge uma forte tensão entre ele, os jovens da rua e os "flanelinhas" que regulam o estacionar dos carros. Arrogante, agressivo, ele impõe sua linha de ação.

Nesta noite, na volta para casa, com Jean acompanhado de dois amigos, a conversa traz a questão da relação com uma mulher negra por parte de um deles, diante do que o pai observa: "eu gosto", gerando no filho a reação: "pai, tu é casado". A que ele responde: "sou casado, mas não estou morto".

A crise financeira da família permite que Jean inicie uma nova vivência social no estrato de tempo contemporâneo, ou seja, um efetivo viver na cidade do Rio de Janeiro, pela primeira vez se misturando no dia a dia com outras classes sociais, que não suas empregadas, vivenciando maior vulnerabilidade, ao lado de descobertas e relações promissoras. Passa por um ciclo de iniciações ao se movimentar sem a proteção da família.

No caminho para o colégio, de início pouco à vontade, logo ele se ajeita. É cortês e gentil com os que estão a sua volta no ônibus. E não tarda a ocasião 
em que uma morena bonita vem sentar-se ao seu lado. Uma vez notada por ele, há olhares e os dois se apresentam. "Meu nome é Jean, muito prazer". "O meu é Luiza". Iniciam uma conversa que logo revela a mútua simpatia.

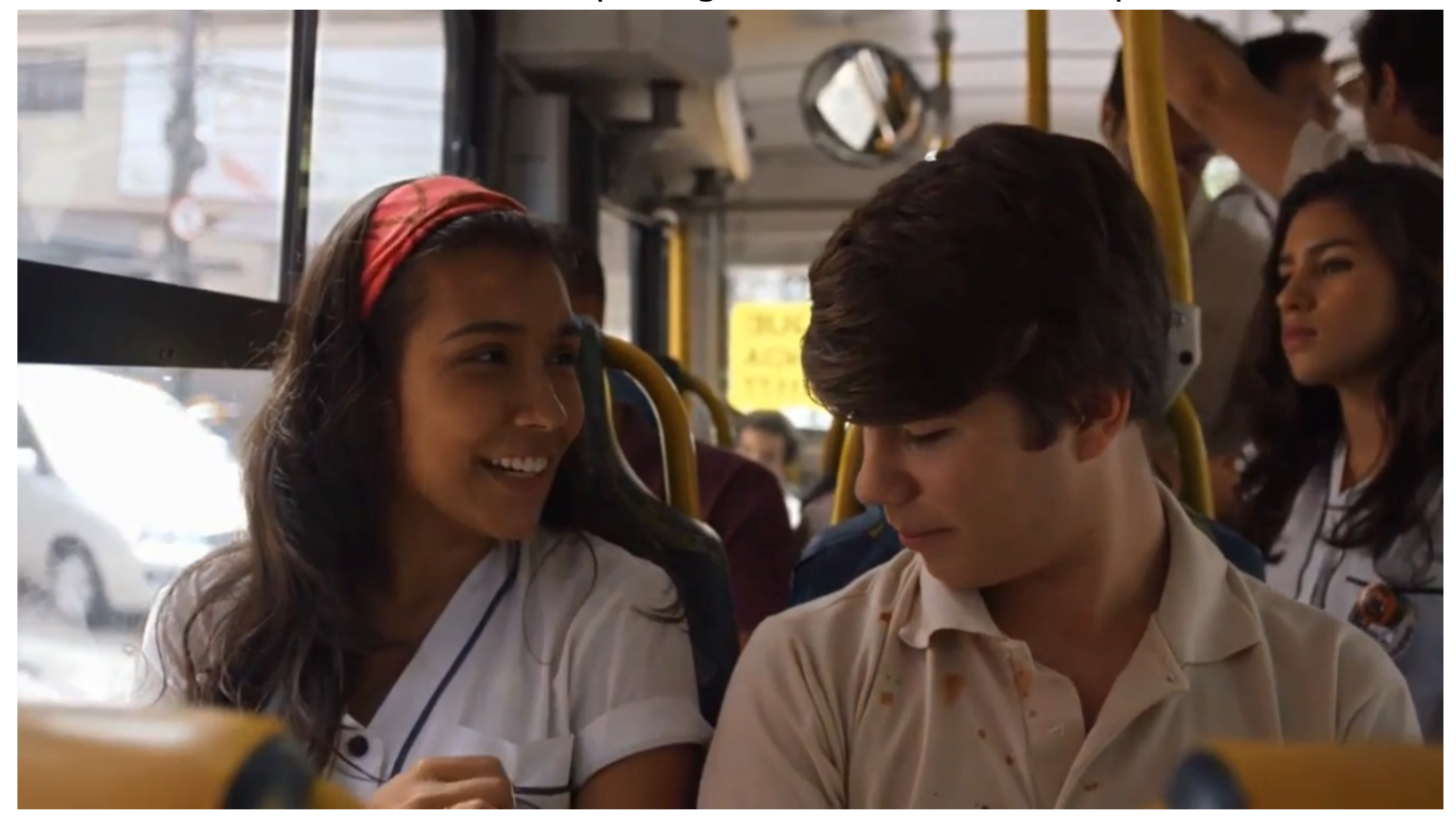

Figura 5

Ela estuda num colégio e quer ir para a faculdade e fazer engenharia. Ele pergunta: "gosta do colégio?". "Amo". Ele fala de suas opções e agora acrescenta "produção musical". O que anima a conversa, dado que ambos têm o tocar violão como hábito e esse é ponto positivo na aproximação desejada.

No ônibus, terminam de conversar combinando um encontro num forró da Lapa, onde têm a ocasião de dançar e sentir maior intimidade. Lembramos dos conselhos de Severino, que ele não consegue seguir. Torna-se clara a inexperiência de Jean, desajeitado e sem élan. Ele assume, diante de Luiza, que mentiu, nunca havia ido a um forró. Ela reage com humor. Os dois se abraçam e se beijam. Fica no horizonte um novo encontro. Desta feita, logo ele liga para seu pai dizendo já estar no ônibus de volta para casa.

Na noite seguinte, em conversa com Rita, ele conta que conheceu uma garota que mora na Rocinha. Rita, com ironia, comenta: "Rocinha! sua mãe vai 'adorar' saber disto". Quando a empregada Ihe pergunta se já transaram, 
ele silencia. "Tu é frouxo demais". Ele faz carinho na perna dela e diz que ela podia Ihe ensinar algumas coisas. Quando tenta beijá-la, ela recua, aceitando apenas um beijinho rápido, dizendo: "vai embora, vai para tua cama; pode sonhar comigo que amanhã eu vou trocar os lençóis". Ele cumpre a ordem dela. Quando só, ela sorri.

Rita está certa nesta observação irônica em que brinca com o desejo de Jean e a insatisfação dele, compensada lá em seu quarto e sob os lençóis. Há nele um sentimento de posse que terá clara expressão quando ele recebe colegas do colégio para estudar em sua casa. Ela atende às visitas com gentileza e provê o necessário nos comes e bebes próprios à ocasião. Um dos amigos de Jean se entusiasma e começa um jogo de sedução com ela, que não rejeita o flerte do modo como o anfitrião gostaria. Enciumado, ele usa vários pretextos para afastar o colega da empregada. Ela percebe tudo com bom humor.

No espaço extramuros, Jean reencontra Luiza no ônibus e combinam um encontro na praia no fim de semana. Mais um lance do namoro. Sentados na areia, trocam carinhos e beijos. Curioso, Jean pergunta com quem ela mora; ela responde que mora com a mãe. "na Rocinha?". "Não. Em São Conrado". E fica curiosa quanto ao motivo de ele pensar que ela mora na favela. "Foi por causa da cor da minha pele?". "Não, foi porque você sempre desce do ônibus no ponto da Rocinha".

Na rotina da família, há o dia da piscina, em que faz parte do lazer a conversa, tomada pela câmera em plano geral, sem atenção aos detalhes. Há o clima de descontração que desta vez acaba sendo interrompido por uma forte queda do pai, um acidente que preocupa os filhos e é tema da conversa do casal quando ele já está dentro da casa. Um diálogo que logo se desloca para a questão do dinheiro, o que reforça, para o espectador, a metáfora presente na queda que evidencia a vulnerabilidade de uma figura que sempre age como se estivesse no domínio das situações. Não por acaso, ela lhe diz: "você precisa é engolir o seu orgulho". Algo que, no caso dela, já está bem 
resolvido, dadas as aulas em que ensina francês em casa e a já declarada intenção de assumir vendas a domicílio para um círculo de amigas e novos contatos a serem feitos.

Severino volta a ser assunto na conversa entre marido e mulher, pois ele entrou com processo na justiça do trabalho, que, segundo o investidor, "nunca dá sentenças favoráveis ao patrão". O que é óbvio em casos como o dele que age como se vivesse em outro tempo. Por sua vez, Jean, depois de beijar Luiza num ônibus, avista Severino na van de uma empresa. Fica agitado, pois constata que ele não tirou férias. Foi despedido pelo pai e está em outro emprego.

Nessa alternância entre os lances da nova vida de Jean e o dia a dia na Casa Grande, sua confidente Rita passa por um aperto quando Sônia reage a uma informação de Noêmia, cozinheira que divide com Rita vários serviços da casa. Ela diz à patroa que encontrou na cesta de lixo da casa uma "camisinha" usada. Esta reage. O assunto exige uma explicação, pois é algo grave que precisa ser investigado. De imediato, vai ao quarto de Rita e revira seus pertences. Acaba encontrando fotografias dela nua, fotos eróticas. Incontinente, vai à copa para pressioná-la: "quem tirou estas fotos?", ao que responde com convicção: "não se preocupe, não foi ninguém da sua família. Juro".

Esse confronto em seu momento de maior tensão é filmado numa longa tomada de perfil das duas em plano americano, sem cortes, o que ressalta a emoção de Rita muito deprimida e chorosa enquanto ouve a patroa lhe dizer que, desde que a recebeu anos atrás, a tratou como se fosse sua filha e que tais coisas não podiam acontecer. A conversa parece encerrada e Rita começa a se afastar, mas resolve retornar e encarar Sônia, afirmando que esta lhe deve um pedido de desculpas por ter entrado no seu quarto para remexer seus pertences. Uma ação corajosa em que avança o sinal frente às regras da casa, tratando Sônia de pessoa para pessoa com dignidade, sem ser servil. Podemos supor que ela deverá pagar caro por esta altivez. Além disso, o marido ouviu a conversa. 


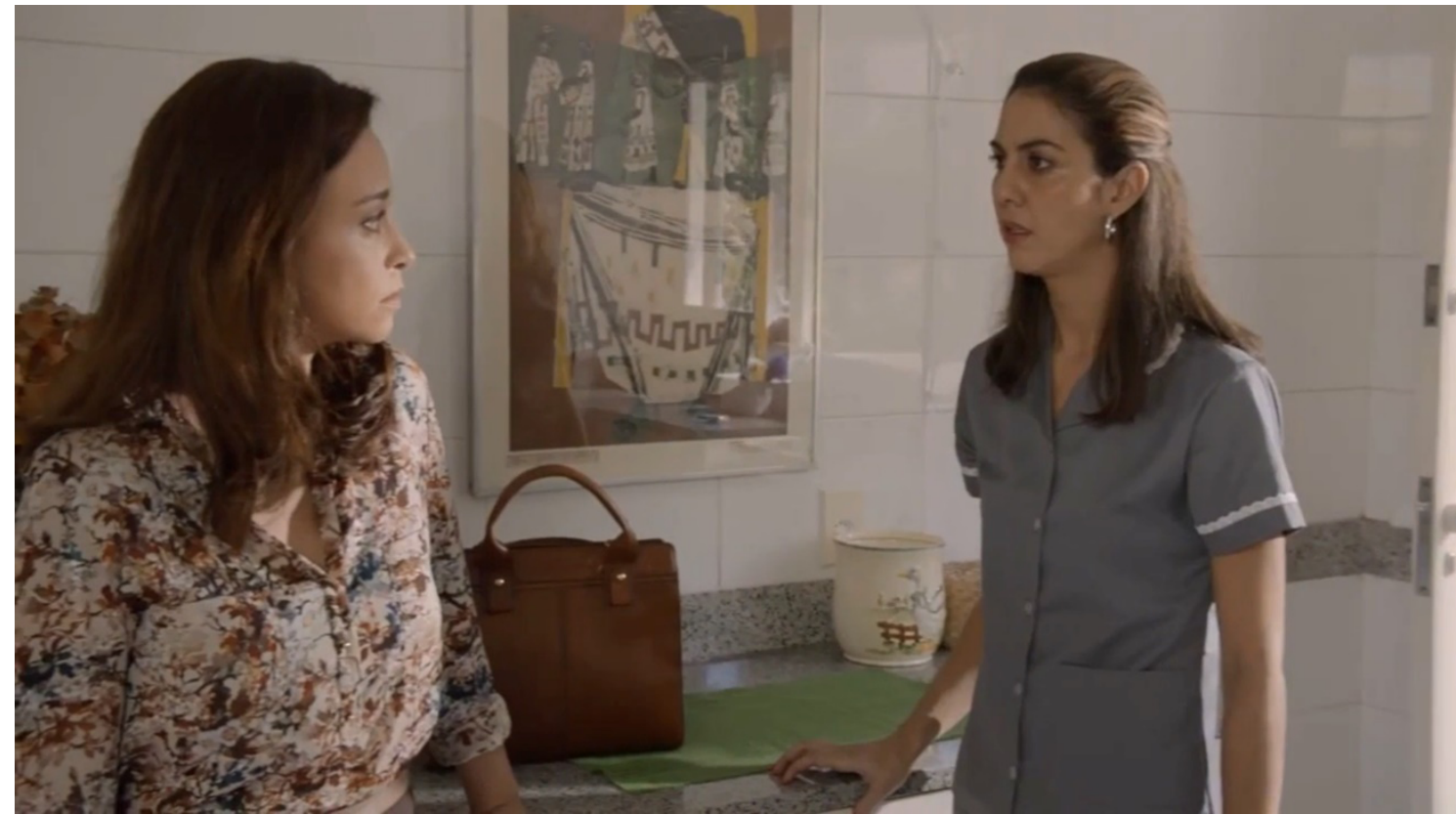

Figura 6

Estes são lances que marcam o contraste entre a forma de Jean se relacionar com Rita, desde que fora de vista, e a postura autoritária de sua mãe, que assume um tom de guardiã da moralidade diante de qualquer indício de atravessamento de sinal. No momento, o filho não estava em casa e não pôde ser chamado para qualquer esclarecimento de sua parte.

Longe de sua confidente, ele está em algum lugar em São Conrado, na cama com Luiza. Seria num motel ou na casa dela vazia? Assim, seu namoro alcança um novo patamar nas preliminares e promete uma efetiva relação sexual que, de repente, é sustada por Luiza. Ela afasta a mão dele que se encaminhava debaixo de sua roupa para a vagina. Feito isso, ela Ihe diz: "eu sou virgem".

Não é ainda desta vez que ele consegue "ir além do beijo". Jean respeita a atitude dela, valendo neste momento mais o afeto do que a frustração, não sem um senso compensatório de que não foi por culpa dele que a relação se interrompeu. A conversa tem andamento nos termos da curiosidade de Luiza, que Ihe pergunta com quem foi sua "primeira vez", curiosidade que ele não satisfaz de imediato. Faz uma careta do tipo "deixe eu ver" e não responde. 
Ela ri e pergunta: "foi com uma puta?" Ele diz que sim, o que não se ajusta ao que já sabemos. E ainda acrescenta que foi levado pelo motorista Severino, algo que não se coaduna com a conversa entre eles no carro da família. Enfim, não quis passar a vergonha de dizer "não". Um passo em falso no diálogo que é remendado pela frase: "eu queria que tivesse sido com você, mas quando rolar vai ser especial".

Para fechar a sequência, voltamos à Casa Grande, onde se consuma a despedida de Rita. Ela é levada até o portão por Noêmia. Todo um ciclo se encerra nessa cena, mostrada à distância de forma nitidamente simbólica na caracterização da perspectiva de alguém que observa o que se passa no portão, dada a forma como se articula o campo/contracampo. No plano inicial, a câmera, colocada dentro da casa, focaliza a cena através de uma janela que ganha destaque na imagem, pois exibe, em primeiro plano, duas grossas linhas verticais e duas horizontais que formam o xadrez em que estão assentados os vidros. Isso produz um efeito de prisão a quem está, pela janela, observando à distância a cena do adeus de Rita. No contracampo, com a câmera fora da casa, vemos atrás das grades da janela o rosto de Natalie a observar, não por acaso, o que se passa no portão (nunca morreu de amores por Rita). Confirma, assim, aquele efeito de prisão que resume em imagem sua própria situação na dinâmica da casa.
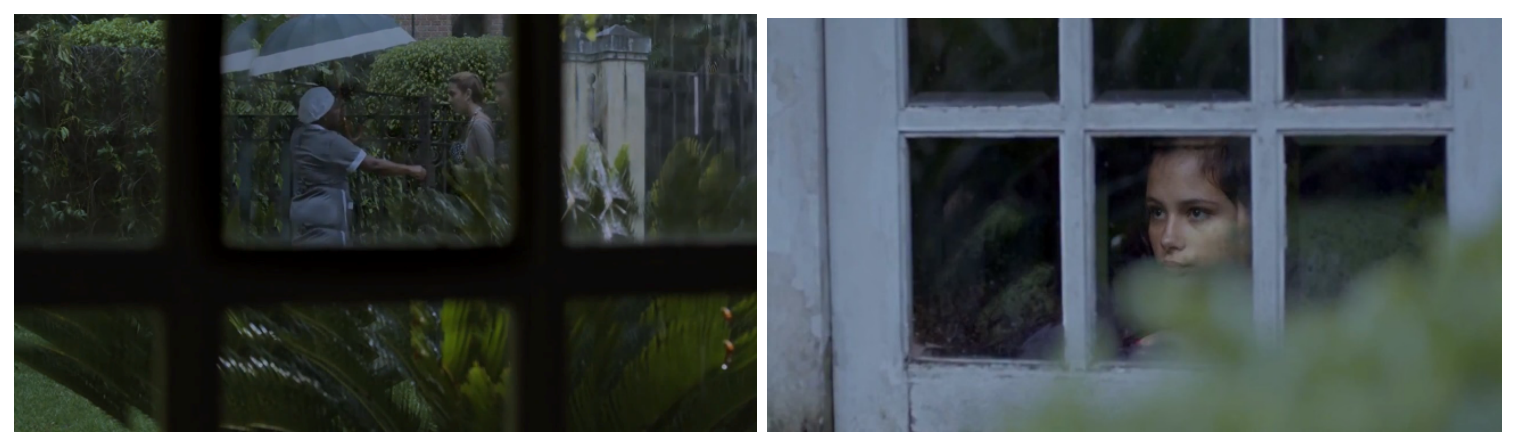

Figuras 7A e 7B

\section{Novos capítulos do "romance de formação" de Jean aos 17 anos}

Em sua mescla de coragem e desajeito ao assumir novas relações, e com o contato efetivo com o mundo capaz de Ihe franquear novas experiências, Jean 
prossegue em sua marcha nesses "dias de aprendizado", para citar um gênero de ficção que, no final do século XVIII e primeiras décadas do XIX, constituiu o chamado "romance de formação", centrado na figura de um jovem em sua lida com o impacto do mundo no qual inicia seus movimentos; uma forma presente nas obras de Goethe, Stendhal e Balzac, por exemplo (Moretti, 2020).

A interação diária com a cidade o projetou em nova fase de vida, inserindo-o em outro estrato de tempo em que se dá a vigência plena do presente com seus desafios e oportunidades. Tal interação o fortalece, não sem tropeços no caminho, e está claro que sua relação com moças inseridas na experiência contemporânea Ihe oferece a chance de ajustar melhor seus anseios.

Um sinal importante desta nova relação com o mundo extramuros se evidencia numa sequência que se abre com a imagem de Jean em primeiro plano a cantar e tocar violão. Está em sua casa, lá no espaço aberto do quintal, por ocasião de uma churrascada oferecida pela família aos amigos. Para nossa enorme surpresa, ele tem Luiza ao seu lado. Seu pai na janela ouve o violão e parece satisfeito.

Seja ou não trazida à baila em função desta presença, a conversa acaba sendo encaminhada por um dos amigos da casa para a questão das cotas reservadas para negros nas universidades públicas. Um dos presentes é radicalmente contra; detesta a instauração de cotas. O assunto está em pauta nos jornais, pois o STF acabara de aprovar a constitucionalidade da Lei da Cotas, tal como fora comentado no colégio. Um professor de Jean abordou o assunto na aula, ouvindo a opinião de vários alunos, a favor e contra. Para a surpresa dos colegas, um estudante negro se manifestou contra, observando que está ali para estudar e alcançar uma vaga em direta competição com os colegas, sem o recurso das cotas.

Com a presença de Luiza, aquela enquete encontra agora um novo capítulo em que a jovem, sempre afirmativa e loquaz, argumenta, e muito bem, a favor das cotas e sua função de reparo de uma dívida histórica, acumulada desde o período da escravidão e perseverada durante mais de um século após a abolição, 
por um sem número de obstáculos efetivos de ordem econômica e social e pelo preconceito de distintas ordens. A discussão é longa, e o dono da casa, que havia lá no início afirmado que "Luiza não é negra nem aqui na China", acaba irritado com a fala dela e se retira. Seus convivas ricos e brancos se reduzem a chavões e preconceitos. Não têm como rebater à altura os argumentos dela e apelam para uma referência à sua identidade racial, forma de insinuar um parti pris de interesse próprio. Luiza, muito irritada, responde com toda a ênfase que é filha de mãe mulata e pai japonês.

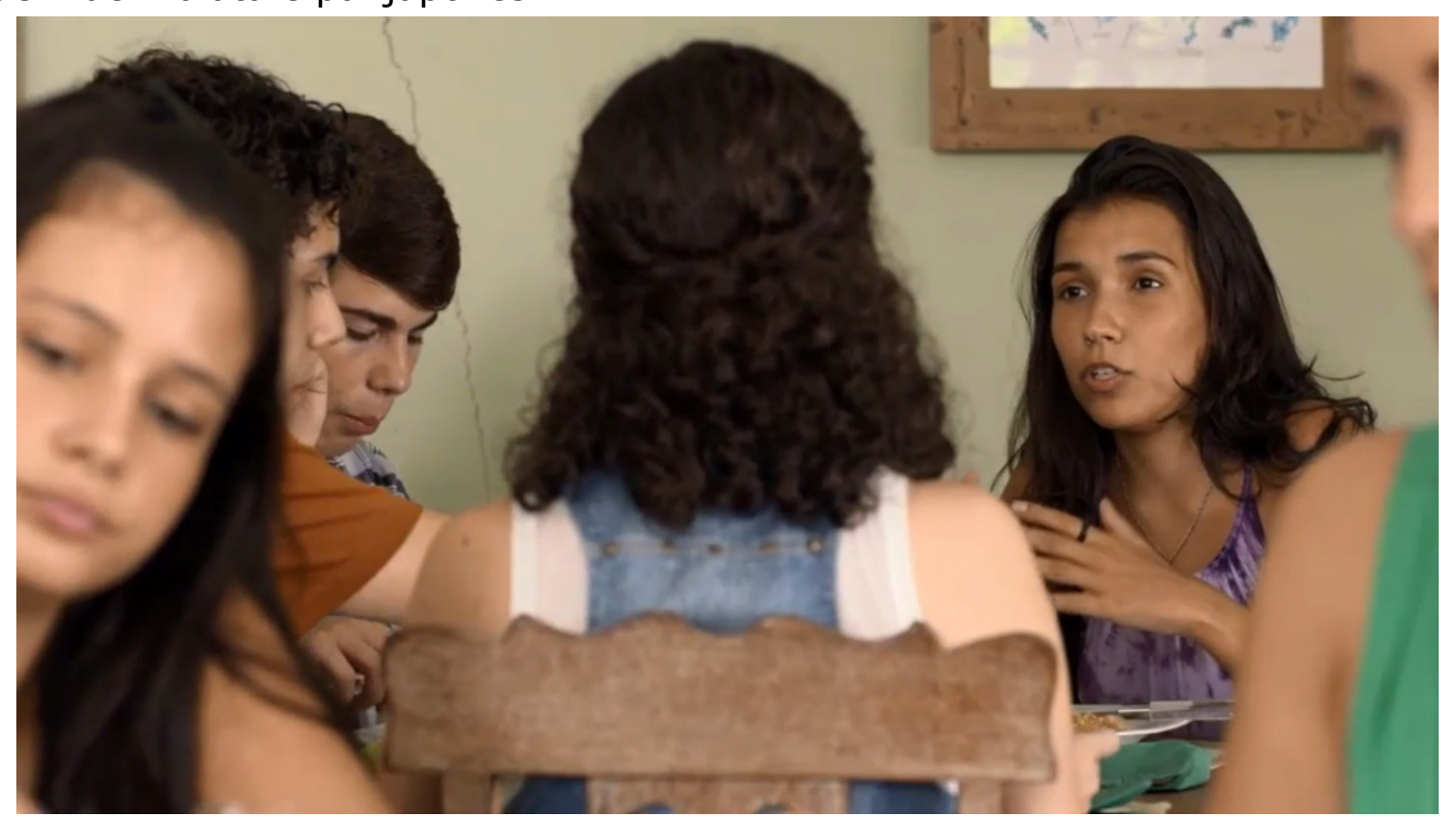

Figura 8

De imediato, Jean a convida para entrar na casa e ir até o quarto dele. A ocasião é boa porque seu pai já estava fora da discussão, ocupado em mostrar a casa para um dos amigos a quem deve dinheiro, falando com ares de corretor elogioso das virtudes da construção e das qualidades da casa que seu dinheiro construiu.

A Casa Grande está à venda. Mais um movimento a que Hugo Cavalcanti é obrigado em função de suas dívidas. Fim de um ciclo e momento de um desgaste que coincide com a nova postura do filho, expressa no gesto de trazer para a "churrascada" a namorada que ele identifica com a Rocinha. 
Uma vez sós no quarto, Jean tenta acalmá-la enquanto ela persevera em dizer que ele é igual ao pai. "Vocês são todos iguais". Ele insiste na diferença e pede para ela esquecer as cotas e o seu pai. "Não sou ele, nem igual a ele; esquece cotas. Eu te amo; o que interessa somos nós". A declaração tem efeito, os ânimos arrefecem e eles permanecem conversando até que uma nova tensão é criada por seu pai ao bater na porta do quarto com insistência. Reclama da porta trancada e o adverte: "você tem uma irmã" (frase cuja conotação já foi comentada). Após responder às batidas na porta com mais batidas pelo lado de dentro, ele convoca Luiza - "vamos embora". Saem às pressas e seguem a pé pelas ruas do bairro até encontrarem um motel.

Uma vez no quarto do motel, a cama é lugar de beijos e carícias que, quando parecem ganhar embalo, são interrompidas, desta vez por ele que, sentindo um descompasso com o momento, recua e, de imediato, joga com o pretexto de ir "ver como é que está a Jacuzzi". Segue para o banheiro e, quando ela vem até ele, pergunta: "você tem certeza que é virgem?". Luiza perde a paciência e resolve ir embora sem mais palavras. Fim de caso?

Uma vez sozinho no motel, ele fica imóvel e chega a adormecer. Será acordado depois por alguém da portaria avisando que já passou a sua hora de ir embora. Sai sem pagar, às escondidas, e vai correndo para casa, ainda abalado pelo "fracasso" com Luiza. Chega em casa afobado, pula o muro e entra pela garagem, fazendo disparar o alarme. O pai vem apressado para verificar a causa e se depara com ele no jardim. Ele tenta falar da dívida no motel. O pai, que está bastante irritado com o sumiço e a forma de entrar na casa, parte para uma repreensão aos gritos, a que ele responde com um desafio, pela primeira vez. Cobra a injusta demissão de Severino, acusa o pai de ter feito um papelão nessa tarde e diz: "pensa que eu não sei o que está acontecendo nesta casa?" e, no calor do "bate boca", manda o pai "à merda". Não leva um sopapo porque a mãe intervém. Jean se afasta do pai e o conflito se dissolve, mas o enfrentamento inusitado com cobranças e ataques frontais à figura paterna deixa claro que há algo novo em sua capacidade de afirmação e iniciativa. 


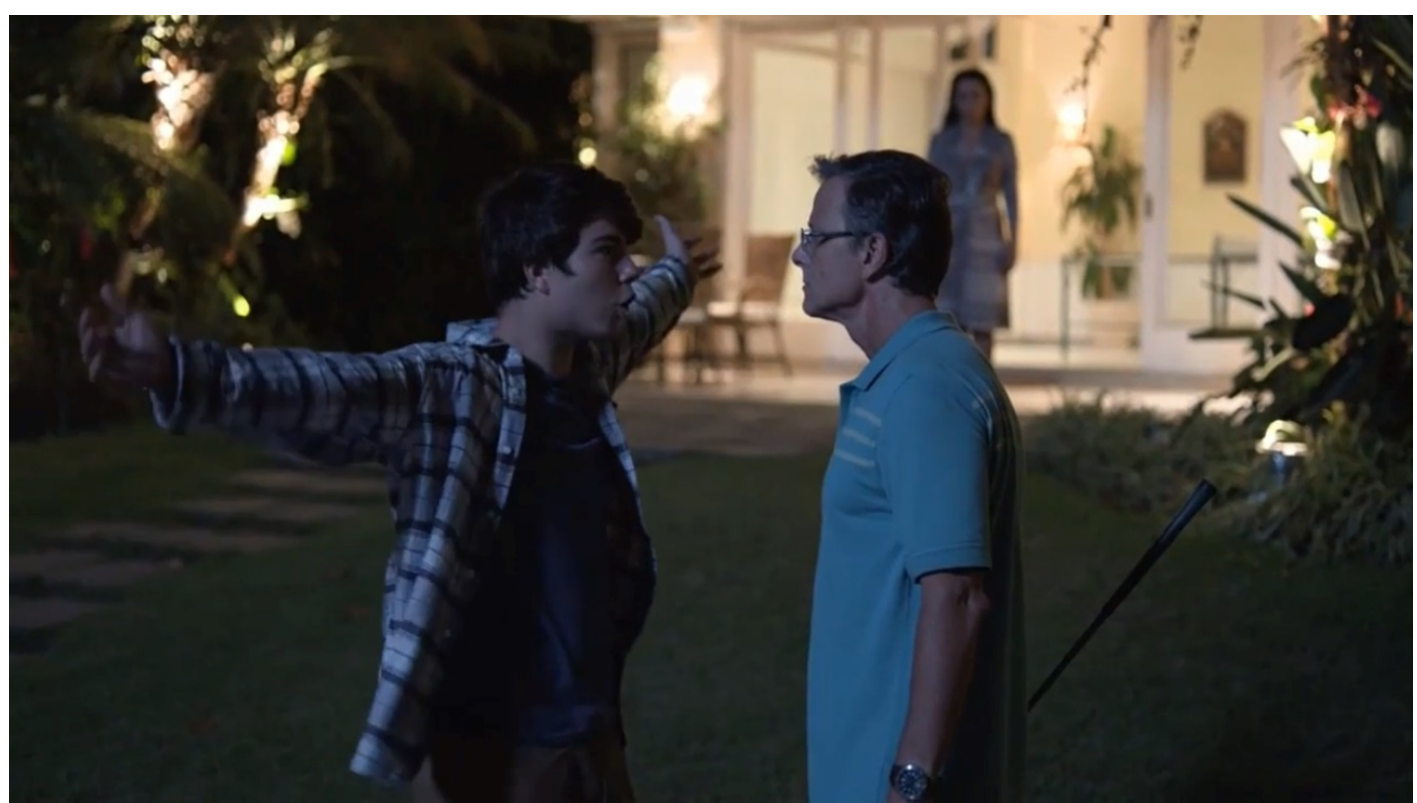

Figura 9

Temos uma elipse indefinida entre a nova sequência e a anterior (quantos dias?). O dado claro é a nova atmosfera, não tanto de descontração, mas de uma rotina marcada por compromissos a cumprir. Lá está a família numa manhã em que tudo começa com a chegada de Noêmia, que foi conversar com a patroa e pedir demissão. Arrumou outro emprego e o "Seu Hugo" está Ihe devendo três meses de salário. O clima é soturno. Sônia lá estava a vender produtos para uma conhecida como planejara na conversa com o marido. Este sai para levar Jean para fazer uma prova importante e, ao deixá-lo, combina o lugar da espera para levá-lo para casa depois. "Boa sorte, meu filho".

Todo esse cerimonial indica se tratar do vestibular. O ambiente parece ser outro, escadaria enorme e certa formalidade. Ao caminhar para a sala do exame, ele encontra Luiza no amplo salão de espera. Cumprimento com beijinho e sorrisos, votos de boa sorte. Seguimos a prova e acompanhamos a saída apressada de Jean para evitar o encontro com o pai. Tem outros planos. Seu rumo é a região do Rio das Pedras, onde vai ao encontro de Severino, que mora ao lado da favela. É recebido num clima de festa, sorrisos, simpatia. Veio para cumprir o roteiro aconselhado pelo motorista em uma conversa que havia se dado no carro. 
O sumiço de Jean é estranhado na Casa Grande e há um momento de pânico quando a mãe atende ao telefone e recebe ordens de quem diz ter sequestrado seu filho. A mãe chora, a irmã se altera, e o pai, não menos nervoso, age com firmeza apostando ser um trote, no que está com a razão. Última cena da família. Aflição? Sim. Até quando?

À noite, Jean vai ao forró com Severino, que faz vibrar o triângulo para marcar o ritmo e canta. Instrumentistas, seus companheiros, o acompanham. Lá está a sorridente Rita, fiel companheira que vem cumprir seu papel de partner, condutora nesta iniciação mais efetiva à noite carioca e ao sexo. Pela primeira vez, ele sente o clima de festa e de prazer descontraído. E segue os primeiros lances do roteiro enquanto dançam no forró ao som de Severino. Vale agora o conselho "Homem tem de ser pegador". Descontração, carinhos, sorrisos, apoio neste reencontro com afetos especiais. Jean encontra o clima que necessita.

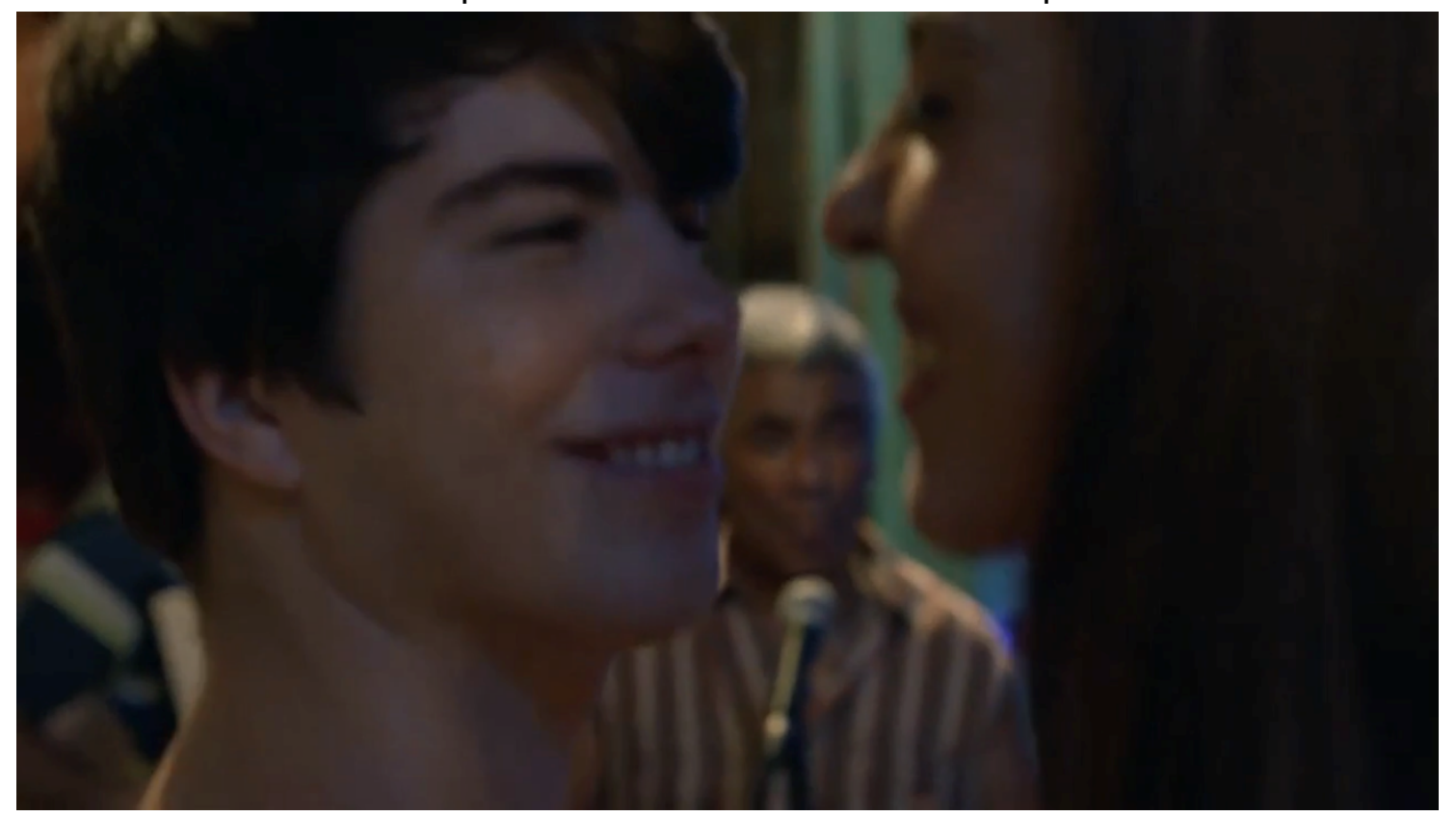

Figura 10

Um corte seco e estamos já na manhã ensolarada em que ele acorda ao lado de Rita, ambos nus. Ele levanta descontraído, veste uma bermuda e se senta no vão da janela aberta da casa de Rita. Tendo ao fundo o céu recortado por uma edificação vizinha, ele expressa uma descontração de "tarefa" cumprida, tudo 
indica que dessa vez realizou o sonho de encontrar o caminho prazeroso de ir além do beijo rumo à consumação do sexo. Está dado o almejado salto.

Compondo o tableau emblemático desse momento especial de vida, a câmera, localizada dentro do quarto, retorna a um plano fixo frontal como na abertura do filme; agora, centrada nesta cena interior, porém marcada pelo horizonte aberto pela janela onde ele se acosta tranquilo, fumando um cigarro e olhando ao longe. Tem ao seu lado uma cortina vermelha e logo abaixo a cama em que está Rita, refestelada a aproveitar o sono. Ao fundo, imagem e som da favela. Tudo se passou agora no terreno que é dela, em contraste com o espaço confinado do seu quarto na Casa Grande, onde não seria digno ceder às vontades do patrãozinho em suas visitas noturnas.

Esse final cristaliza uma superação do passado que não traz aquela máxima "e foram felizes para sempre". Celebra a passagem de Jean para uma outra etapa de desafios e questões a serem resolvidas, começando por seu conflito com o pai e a Casa Grande. Estão criadas as condições para que se lance, de forma mais radical e produtiva, dentro de uma nova dinâmica em sua vida.

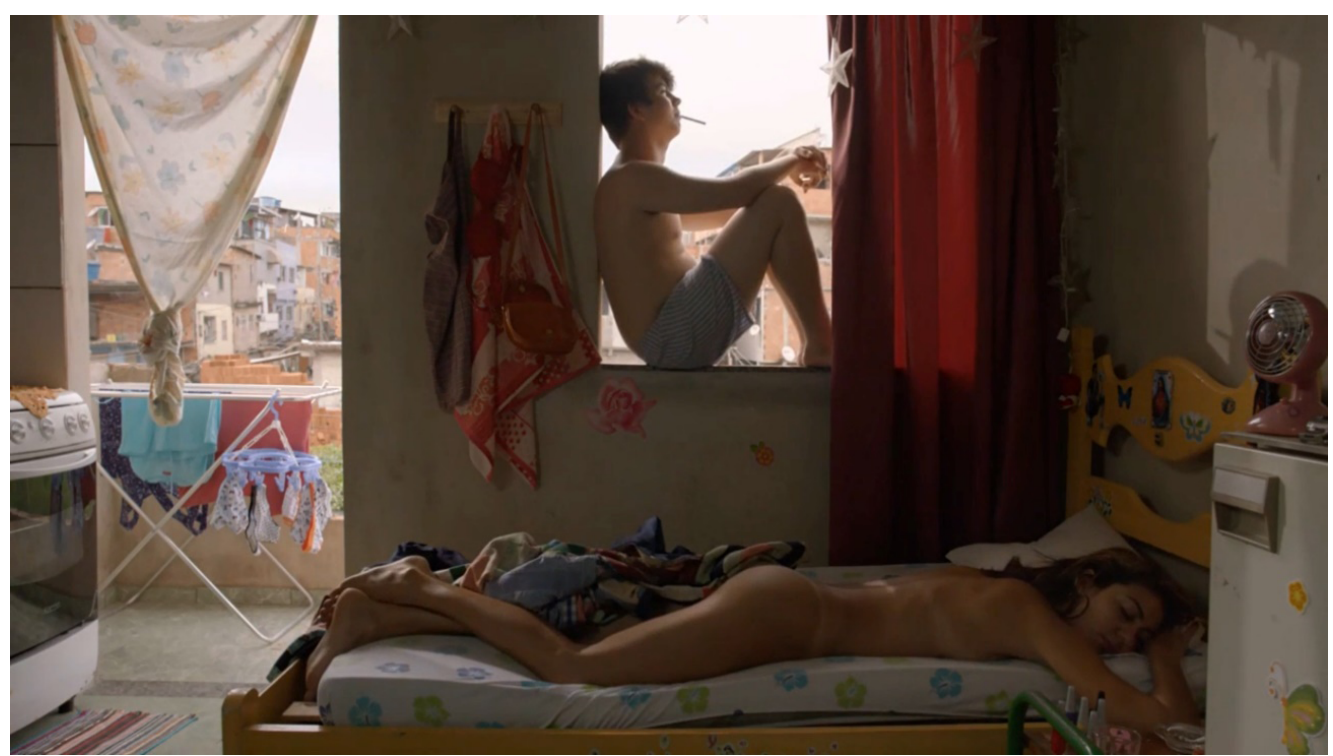

Figura 11

\section{Epílogo}

Em Casa Grande, tivemos de início a caracterização do mundo intramuros e do cordão de proteção ao filho, calibrado para evitar seu mergulho integral na 
dinâmica da cidade. Depois, uma nova situação financeira tornou necessárias providências que lançaram Jean na experiência de abraço pleno da cidade.

Essa vivência do jovem protagonista compõe um percurso que nos traz uma nova variante no modo de colocar em cena o motivo "o passado no presente", não mais trabalhado a partir de um movimento do protagonista do litoral para o sertão. O dado original de Casa Grande é a inversão desse movimento, que agora é feito numa travessia dentro da própria cidade grande. Uma mudança que, considerado o binômio "intramuros versus extramuros", corresponde à passagem de um estrato de tempo no qual sobrevivem as relações de classe que marcam sobrevivências de um passado a outro estrato de tempo plenamente contemporâneo. O extramuros, uma vez tornado efetivo o campo de sua experiência, criou as condições próprias para ele se projetar no habitat urbano em sua diversidade, insegurança, tensões e oportunidades.

\section{Referências}

DUNKER, C. I. L. Mal-estar, sofrimento e sintoma: uma psicopatologia do Brasil. São Paulo: Boitempo, 2015.

KOSELLECK, R. Estratos do tempo: estudos sobre história. Rio de Janeiro: Contraponto; Editora PUC-Rio, 2014.

MORETTI, F. O romance de formação. São Paulo: Todavia, 2020.

TOMACHEVSKI, B. Temática. In: TOLEDO, D. O. (org.). Teoria da literatura: formalistas russos. Porto Alegre: Globo, 1970. p. 169-204. 